\title{
Herbal Therapy: An Alternative against Bovine Teat Papillomatosis in Cattle
}

\author{
Manoj Kumar ${ }^{1 *}$ and Shiv Sharan Pant ${ }^{2}$ \\ ${ }^{1}$ Department of Animal Husbandry, Saharsa-852201(Bihar), India \\ ${ }^{2}$ Touring Veterinary Officer, Aaran, India \\ *Corresponding author
}

\section{A B S T R A C T}

\begin{tabular}{|l|}
\hline Ke y w or d s \\
$\begin{array}{l}\text { Bovine Pappiloma } \\
\text { Virus, Warts, } \\
\text { Cattle, Bai-Mast }\end{array}$ \\
\hline Article Info \\
\hline $\begin{array}{l}\text { Accepted: } \\
\text { 22 January } 2017 \\
\text { Available Online: } \\
\text { 10 February } 2017\end{array}$ \\
\hline
\end{tabular}

Twelve cross breed cow having teat papilloma were successfully treated with Bai-Mast ${ }^{\circledR}$ herbal capsule. Papilloma was start regressing from $5^{\text {th }}$ day after treatment and completely disappeared after $20 \pm 2$ day of treatment without any recurrence. Therefore Bai-Mast ${ }^{\circledR}$ can be used as an alternative for the treatment of papilloma in cattle.

\section{Introduction}

Papillomatosis or warts are benign proliferative tumor affecting almost all species of animal including man throughout the world. Bovine papillomatosis is a contagious disease of cattle as warts/papilloma on skin and mucosa, caused by bovine papilloma viruses (BPV) (Tokura and Kagawa, 1995). In cattle BPV affecting all parts of the body mainly necks, skin of eye lids, teats and lower abdomen. Calves are more susceptible to cutaneous papillomatosis while lactating dairy cows may occasionally suffer from teat papillomatosis. The papillomas are benign tumors and generally regress, but occasionally persist and provide the focus for malignant transformation to squamous cell carcinoma, particularly in the presence of environmental co-factors (Campo, 1997). Generally treatment with lithium antimony tartarate, bismuth preparation and removable by traction or ligation recovery was very poor and recurrence is possible (Radostits et al., 1994).

Bai-Mast ${ }^{\circledR}$ herbal capsule was indicated for mastitis and skin infection in cattle. In recent days herbs had been proven effective against many bacterial and viral diseases without any side effect. Based on this principle, Bai-Mast ${ }^{\circledR}$ herbal capsule was tried for the treatment of bovine papillomatosis in cattle. 


\section{Materials and Methods}

Twelve cross breed cows of age 4 years have papilloma over teats leads to painful milking and mastitis in a dairy farm in Saharsa district of Bihar. All cattle were treated with herbal capsule Bai-Mast ${ }^{\circledR}$ (Shri Baidyanath Ayurved Pvt. Ltd.) at 3-5 caps bid orally for 18-22 days depending upon the severity of infection and age of animals. In case of teat papillomatosis wound was dressed with betadine antiseptic lotion and later on application of camphor mixed coconut oil externally till complete recovery. All animals were observed till 90 days to see any recurrence.

\section{Results and Discussion}

All cattle were showed immense response to the herbal treatment. The papilloma was start regressing after $5^{\text {th }}$ day of treatment and complete recovered after $18-22^{\text {th }}$ day of treatment. There was no recurrence of papilloma after complete recovery. Generally treatment with lithium antimony tartarate, bismuth preparation and removable by traction or ligation recovery was very poor and recurrence is possible (Radostits et al., 1994). This herbal drug therapy had very good recovery rate irrespective of papilloma's nature or size etc. Bai-Mast capsule was shown uneventful response against warts/papilloma may be due to presence of many plants extract which have anti papilloma/antiviral and anti cancereous properties like moringa tree which has powerful anti bacterial, fungicidal and anti neoplastic effects (Fahey, 2003). Turmeric has curcumin, which exhibit antioxidant, antiinflammatory, antiviral, antibacterial, antifungal, and anticancereous activities (Aggarwal et al., 2007). Awala has antiviral, antimicrobial properties (Saeed and Tariq, 2007) and have potential activity against some cancers (Ngamkitidechakul et al., 2010). Kuchla has considerable amount of flavonoids, strychnine and brucine which have anticancer, antimicrobial, antiinflammatory and antioxidant activity (Patel et al., 2012). The Kuth pant contains active principles like saussurine, costunolide, and lactones which exhibit antiviral, anti fungal and anti inflammatory effect (Madhavi et al., 2012). The kulthi plant extracts have proveen anti-papilomagenesis and anti-tumerogenesis effect in Swiss Albino mice (Nanta and Kale, 2011). The Haritaki plant extract was highly effective in inhibiting papilloma and anti carcinogenic activity (Tokura and Kagawa, 1995) may be due to the presence of vital chemical constituents like tannins, saponins, flavanoids, anthroquinones and sorbitol present in the plant. Therefore we conclude that Bai-Mast ${ }^{\circledR}$ capsule containing plants extract have compounds that inhibit papiloma virus and secondary bacterial infection which may help in regression of papiloma/warts.

\section{References}

Aggarwal, B.B., Sundaram, C., Malani, N. and Ichikawa, H. (2007). Curcumin: the Indian solid gold. Adv. Exp. Med. Bio. 595: 1-75.

Campo, M.S. (1997). Bovine papillomavirus and cancer. Vet. J. 154: 175-88

Fahey, J W. (2005). Moringa oleifera: A Review of the Medical Evidence for Its Nutritional, Therapeutic, and Prophylactic Properties. Part 1.

Madhavi, M., Mallika, G., Lokanath, N., Vishnu, M. N., Madhushudhana, C. C. and Mohammad, S. (2012). A review on phytochemical and pharmological aspect of Saussurea Lappa. Int. J. Rev. Life. Sci. 2(1): 24-31.

Nanta, R. and Kale, K. R. (2011). Chemomodulatory Effect of Dolichos Biflorus on skin and fore stomach papillomagenesis in swiss albino mice. Ind. J. Expt. Bio. (49):483-490.

Ngamkitidechakul, C., Jaijoy, K., Hansakul, P., Soonthornchareonnon, N. and 
Sireeratawong, S. (2010). Antitumour effects of phyllanthus emblica L.: Induction of cancer cell apoptosis and Inhibition of in vivo tumour promotion and in vitro invasion of human cancer cells. Phytotherapy Research. 24 (9): 1405-1413.

Patel D. K., Patel, K., Duraiswamy, B. and Dhanabal, S. P. (2012). Phytochemical analysis and standardization of Strychnos nux-vomica extract through HPTLC techniques. Asian Pacific $J$ Trop. Dis. S56-S60

Radostits, O.M., Blood, D.C. and Gay, C.C. (1994). Veterinary medicine, ELBS,
Bailliere Tindall, London, eighth edition, 1127.

Saeed, S. and Tariq, P. (2007). Antibacterial activities of Emblica officinalis and Coriandrum sativum against Gram negative urinary pathogens". Pak. J. Pharm. Sci. 20 (1): 32-5.

Singh, V., Somvanshi, R. and Tiwari, A. K. (2009). Papillomatosis in Indian cattle: Occurrence and etiopathology. Ind. $J$. Vet. Path. 33: 52-57.

Tokura, K. and Kagawa, S. (1995). Anti cancer agent containing chebulanin from Terminalia Chebula. Jpn. Kokai. Tokkyo. J.P.07: 138-165.

\section{How to cite this article:}

Manoj Kumar and Shiv Sharan Pant. 2017. Herbal Therapy: An Alternative against Bovine Teat Papillomatosis in Cattle. Int.J.Curr.Microbiol.App.Sci. 6(2): 1194-1196. doi: http://dx.doi.org/10.20546/ijcmas.2017.602.135 